\title{
COMMENT
}

\section{The Columnist Manifesto}

\author{
Gregory A Petsko*
}

A specter is haunting Europe - the specter of the euro. As I write this, the likelihood that European monetary unity will break apart like a dropped porcelain doll looms larger than at any time in the past 2 years. The resulting financial upheaval would certainly send both that continent, and much of the rest of the world, into a deeper recession, if not into an actual economic depression. Even if the single currency manages to survive, the austerity measures that are being implemented - foolishly, in my opinion - throughout most of the EU member nations (and that even Britain appears to be hell-bent on following, at least in part) almost certainly guarantee that the worst recession in half a century will continue for several more years.

Although financial barons and central bankers persist in painting the current crisis as a morality play, with spendthrift debtor nations dragging down the rest of the European Union, reality is actually quite different. Many of the nations in deepest trouble, like Ireland, actually had low public debt. The crisis was due more to skewed balance of payments between Germany/France and the nations on the Eurozone periphery, and reflects the underlying flaw in the creation of a monetary union without concomitant fiscal unity. It can probably be solved only if the European Central Bank decides to act as a lender of last resort and if wealthier EU countries accept a higher inflation rate, so that the debtor nations can regain solvency, but higher inflation erodes the value of fixed assets, and banks and financial services companies tend to hold lots of fixed assets.

Therefore it seems unlikely that the present problems will be solved rapidly, and as long as misguided, or greedy, political and economic leaders continue to insist that the cure for low private spending and high unemployment is the type of austerity that is guaranteed to produce even worse low private spending and high unemployment, most European nations will be feeling severe economic pains for some time to come.

Rosenstiel Basic Medical Sciences Research Center, Brandeis University, Waltham, MA 02454-9110, USA

*Correspondence: petsko@brandeis.edu
Which is a huge problem for science, of course. Scientific research is expensive, and has an inflation rate higher than the nominal inflation rate for goods and services. Scientific research typically has a long-term payoff - something politicians don't like when everyone is dealing with serious short-term problems. Scientists tend not to be very politically active as a species, and are in sufficiently small numbers that their votes, which in any case largely favor leftist candidates under most circumstances, aren't highly sought after. Desperate politicians, looking for budgets to cut, often slash governmentfunded science programs to the bone. Claims that the private sector should, and will, pick up the slack, dubious to begin with, are clearly nonsense when the economy as a whole is not expanding. Times like these are bad times for science.

Nor is the United States immune. Economically, the US is so closely connected to Europe that when the EU sneezes, we get the flu - if we didn't have it already, which, of course, we do. The Obama administration seems unable, or unwilling, to push through additional stimulus spending - the one thing that could ease unemployment and increase demand (and don't let conservative hacks fool you; this is a demand-fueled recession). The Democrats in Congress appear to be of an unusually spineless sort, and are pretty much useless. As for the Republicans, well, their idea of solving the problem is tax cuts for the rich, justified under the mantra of 'job creation', despite the fact that the wealthiest Americans typically make their money in ways that create very few jobs.

And somehow, all of this has become conflated with the idea that, above all else, we have to reduce the federal budget deficit. There are many reasons why that particular discussion ought to bring out the cynic in anyone, but I'll settle for this: if the Republicans really cared about the deficit, they would be pushing for tax increases instead of tax cuts, since the latter are guaranteed to increase the deficit. Why the Democrats have allowed deficit reduction to be the central issue of the day, instead of, oh, say, unemployment, is something I leave for future historians of the collapse of Western Civilization to argue about.

So while Europe is gradually slipping into an economic malaise that may lead to the death of the euro (and which, not coincidentally, is also seeing the rise of nationalist 
and potentially authoritarian right-wing political parties in Austria, Hungary and even Finland), the US is showing its international leadership by doing pretty much the same thing. (And that may even include the nationalist/ authoritarian party trend, if recent statements from Presidential candidates such as Newt Gingrich are any indication.) Federal funding for science is declining in inflation-adjusted dollars; success rates for research grant applications are at historic lows; young people are being driven out of science by the uncertain climate for funding, publication and hiring; older scientists are being driven into premature retirement by many of the same factors; public support for science is being eroded by the rise of religious fundamentalism - and if all this makes me sound like Chicken Little, well, let me remind you that sometimes the sky really is falling.

I started writing this column more than 10 years ago because I wanted to comment on the genomics revolution and its effect on science and society. The good folks at Genome Biology have allowed me to do that, and to opine about pretty much anything else as well, so over the years I have written about subjects ranging from diets to evolution to the importance of the arts and humanities in higher education. It was that last topic, which was the subject of my open letter to the president of the State University of New York at Albany [1], that led to the musings in this one. That commentary has been downloaded more than 130,000 times; has been translated into at least ten languages; has been reprinted more than 20 times that I know of; and has - there is really no other way to put this - gone viral on the Internet like a YouTube video of a philandering politician. Moreover, I received over 500 emails about the column, most of which thanked me for saying what I said, often remarking on my courage in doing so.

Now that surprised me, because I don't think it took any particular courage to stand up for the liberal arts, but those messages reminded me that I do often get emails and letters of a similar nature whenever I write about controversial subjects such as evolution, science and religion, the follies of elected officials and scientific funding agencies, and so forth. People seem to be both pleased and surprised that a scientist would speak out and I am pleased and equally surprised that they feel that way.

Yet when I think about it, perhaps I shouldn't be surprised at all. Science is a haven for people who don't like to sully their hands with the messiness of real-world politics and who abhor controversies that lead to confrontation. In addition, history teaches us that the occasional scientist who sets him- or herself up as a popularizer of our subject has often been ridiculed as a glory-seeker and dismissed as a scientific lightweight witness the near ostracism of the late Carl Sagan, who never got the credit he deserved for some very important ideas, such as nuclear winter. Increasing demands on academic scientists to garner even more funding and publish even more comprehensive studies have also left little time for engagement with the lay public over the issues of the day.

But the response to these columns, especially of late, has convinced me that there is an appetite for such engagement and support for those who do it. It has also reminded me that the written word has a power that we often overlook.

Consider the number of books that have sparked revolutions in thought, and occasionally actual revolutions as well. The Communist Manifesto. On the Origin of Species. The Nature of the Chemical Bond. The Double Helix. The Wealth of Nations. Uncle Tom's Cabin. The Bible. The Koran. The 95 Theses. The Federalist Papers. I could list a hundred more, and as many essays. There is a hunger on the part of people for ideas, for knowledge, for certainty, and for something larger than themselves that can be served. Demagogues of the left and right have recognized that fact for centuries, but scientists have acted like they know it on only rare occasions.

Never has there been a better time to change that history. Op-ed pages in newspapers all around the globe are available for well-written commentaries on the importance of basic research, the need to translate more discoveries into cures and inventions, the stupidity of the boom-and-bust cycles of scientific funding, the evidence for global warming, the certainty of evolution, the importance of the separation of church and state, the power of evidence-based thinking over mindless belief in authority, and countless other matters where practicing scientists have opinions worthy of the public's attention. If we don't take up our pens (metaphorically speaking - I haven't actually written anything in 10 years), the lunatic fringes of politics, religion and pseudo-science have plenty of people who will. If 1 in 20 attempts on our part to publish facts and to show the lay public who we are and what we do actually make it into print, it will represent a huge increase in the trickle of today.

But if we remain silent, then our decline will continue, perhaps even accelerate. If we say nothing, others will put words in our mouths. If we do not explain what science is, others will deride it as just another belief system, and people who read only that will not know that it is a lie. Don't think that our continued support by governments and the public is inevitable, or something we are entitled to. It must be fought for and earned, proclaimed and justified. The tottering of the euro may presage a period when science is seen in some European nations as an expensive luxury that cannot be afforded. The rise of the ignorant and the greedy in American politics may be a harbinger of a similar perspective here. Only our 
increased willingness to speak out may stand between a world brightened by science and an oncoming darkness.

Scientists of the world, write. To paraphrase Bob Dylan: when you have nothing, you have nothing to lose.

Published: 28 December 2011

\section{References}

Petsko GA: A Faustian bargain. Genome Bio/ 2010, 11:138.

doi:10.1186/gb-2011-12-12-136

Cite this article as: Petsko GA: The Columnist Manifesto. Genome Biology 2011, 12:136 